\title{
Lithium Hexastannate: A Potential Material for Energy Storage
}

\author{
Yohandys A. Zulueta and Minh Tho Nguyen*
}

The prediction of a new lithium compound, $\mathrm{Li}_{2} \mathrm{Sn}_{6} \mathrm{O}_{13}$, is made from a combined first-principles and classical force-field approach. The electronic, structural, and mechanical properties of monoclinic $\mathrm{Li}_{2} \mathrm{SnO}_{3}, \mathrm{Li}_{2} \mathrm{Ti}_{6} \mathrm{O}_{13}$, and $\mathrm{Li}_{2} \mathrm{Sn}_{6} \mathrm{O}_{13}$ are explored. The calculated results for the equilibrium lattice parameters are in agreement with the available experimental data. The thermodynamic stabilities of $\mathrm{Li}_{2} \mathrm{Ti}_{6} \mathrm{O}_{13}$ and $\mathrm{Li}_{2} \mathrm{Sn}_{6} \mathrm{O}_{13}$ are evaluated. Both compounds are demonstrated to be thermodynamically stable with standard molar formation enthalpies of -5553 and $-6740 \mathrm{~kJ} \mathrm{~mol}{ }^{-1}$, respectively. Reaction energies for delithiation of 6.41 and $6.90 \mathrm{eV}^{\text {atom }}{ }^{-1}$ are also determined for $\mathrm{Li}_{2} \mathrm{Sn}_{6} \mathrm{O}_{13}$ and $\mathrm{Li}_{2} \mathrm{Ti}_{6} \mathrm{O}_{13}$, respectively. The predicted voltage of $\mathrm{Li}$ insertion/extraction process per $\mathrm{Li}^{+} / \mathrm{Li}$ is $1.6 \mathrm{~V}$ for $\mathrm{Li}_{2} \mathrm{Sn}_{6} \mathrm{O}_{13}$, comparable to its isostructural counterpart $\mathrm{Li}_{2} \mathrm{Ti}_{6} \mathrm{O}_{13}$. Electronic band structure calculations indicate the insulating character of $\mathrm{Li}_{2} \mathrm{SnO}_{3}$ with an indirect band gap of $4.4 \mathrm{eV}$, whereas both $\mathrm{Li}_{2} \mathrm{Ti}_{6} \mathrm{O}_{13}$ and $\mathrm{Li}_{2} \mathrm{Sn}_{6} \mathrm{O}_{13}$ appear to be semiconductor compounds with band gaps of 3.1 and $3.0 \mathrm{eV}$, respectivley. The energy barriers for $\mathrm{Li}^{+}$migration amount to $\approx 0.5 \mathrm{eV}$ for both materials. Elastic stiffness coefficients and bulk, shear and Young's moduli were also calculated. The $\mathrm{Li}_{2} \mathrm{Sn}_{6} \mathrm{O}_{13}$ derivative is mechanically stable and can be predicted to be a brittle compound that is more resistant to volume change than $\mathrm{Li}_{2} \mathrm{Ti}_{6} \mathrm{O}_{13}$. If the $\mathrm{Li}_{2} \mathrm{Sn}_{6} \mathrm{O}_{13}$ compound could experimentally be prepared by using ion exchange, it could potentially be an efficient material for anodes in lithium-ion batteries.

\section{Introduction}

Alkali-metal hexatitanates with a tunnel structure $\left(\mathrm{A}_{2} \mathrm{Ti}_{6} \mathrm{O}_{13}, \mathrm{~A}=\mathrm{Na}^{+}, \mathrm{K}^{+}\right.$, or $\left.\mathrm{Li}^{+}\right)$ exhibit large specific surface areas and structural anisotropy. ${ }^{[1-3]}$ Of the possible technological applications, these compounds could be used as anodes in the field of high performance batteries, which is a continuing focus of significant attention. ${ }^{[4-6]}$ These compounds have the appropriate structural type for this purpose.

These structures contain a one-dimensional (1D) tunnel space within their lattice structure, favoring fast $\mathrm{Li}^{+}$-ion conduction. ${ }^{[5-7]}$ Zhang and coworkers studied the structure and photocatalytic and electrochemical properties of $\mathrm{Li}_{2} \mathrm{Ti}_{6} \mathrm{O}_{13}$ nanobelts prepared from $\mathrm{Na}_{2} \mathrm{Ti}_{6} \mathrm{O}_{13}$ nanobelts as a template (parent) structure via a $\mathrm{Li}^{+} / \mathrm{Na}^{+}$ ion-exchange method. ${ }^{[8]}$ Their results revealed that $\mathrm{Li}_{2} \mathrm{Ti}_{6} \mathrm{O}_{13}$ exhibits higher photocatalytic efficiency than $\mathrm{Na}_{2} \mathrm{Ti}_{6} \mathrm{O}_{13}$, attributed to the expansion of tunnel space in the former structure compared to $\mathrm{Na}_{2} \mathrm{Ti}_{6} \mathrm{O}_{13}$ nanobelts. The expansion of the tunnel space was also previously reported in Refs. [9-11]. This expansion is ascribed to the change of coordination of lithium into a $\mathrm{LiO}_{4}$ planar hybridization instead of the

Prof. M. T. Nguyen

Computational Chemistry Research Group

Ton Duc Thang University

Ho Chi Minh City, Vietnam

E-mail:nguyenminhtho@tdt.edu.vn

Prof. M. T. Nguyen

Faculty of Applied Sciences

Ton Duc Thang University

Ho Chi Minh City, Vietnam

Dr. Y. A. Zulueta

Facultad de Ciencias Naturales y Exactas

Departamento de Fisica

Universidad de Oriente

CP 90500, Santiago de Cuba, Cuba

Prof. M. T. Nguyen

Department of Chemistry

KU Leuven

B-3001 Leuven, Belgium

E-mail:minh.nguyen@kuleuven.be

The ORCID identification number(s) for the author(s) of this article can be found under https://doi.org/10.1002/pssb.201700669.

DOI: 10.1002/pssb.201700669
$\mathrm{NaO}_{8}$ coordination existing in $\mathrm{Na}_{2} \mathrm{Ti}_{6} \mathrm{O}_{13}$. Density functional theory (DFT) confirmed the $\mathrm{LiO}_{4}$ planar coordination in this material. ${ }^{[9]}$

Recently, we developed a transferable force field for classical simulations to model the bulk properties of different lithiumbased materials, such as $\mathrm{Li}_{2} \mathrm{MO}_{3}$, where $\mathrm{M}=\mathrm{Sn}^{4+}, \mathrm{Si}^{4+}$, and $\mathrm{Ti}^{4+} \cdot{ }^{[12]}$ These compounds have similar technological applications to $\mathrm{Li}_{2} \mathrm{Ti}_{6} \mathrm{O}_{13}$ as a result of their fast ion conduction. The transferability of this new force field has been successfully verified by testing the structural and mechanical properties of monoclinic $\mathrm{Li}_{2} \mathrm{Si}_{2} \mathrm{O}_{5}$ and $\mathrm{Li}_{2} \mathrm{Ti}_{6} \mathrm{O}_{13}$ compounds. The experimental properties of these materials were well reproduced by the theoretical simulations. ${ }^{[12]}$

In this context, we have extensively applied this simulation approach in the search for new compounds featuring better properties for ionic conduction. Our calculated results predict that lithium hexastannate $\left(\mathrm{Li}_{2} \mathrm{Sn}_{6} \mathrm{O}_{13}\right)$ may be appropriate for this purpose. In addition, monoclinic $\mathrm{Li}_{2} \mathrm{Sn}_{6} \mathrm{O}_{13}$ could also be experimentally prepared via the $\mathrm{Ti}^{4+} / \mathrm{Sn}^{4+}$ ion-exchange method from the known $\mathrm{Li}_{2} \mathrm{Ti}_{6} \mathrm{O}_{13}$ structure. 
In this study, we report predicted results for the stannate derivative with the hope that it could stimulate further experimental research. We report not only the structural, mechanical, thermomechanical stability and electronic properties of monoclinic $\mathrm{Li}_{2} \mathrm{Sn}_{6} \mathrm{O}_{13}$ via empirical force-field calculations, but also those obtained using DFT methods as a further verification of the force-field-based results.

\section{Results and Discussion}

\subsection{Methods and Structures}

For comparative purposes, we consider the known compounds, $\mathrm{Li}_{2} \mathrm{SnO}_{3}$ and $\mathrm{Li}_{2} \mathrm{Ti}_{6} \mathrm{O}_{13}$, together with the new compound. $\mathrm{Li}_{2} \mathrm{Sn}_{6} \mathrm{O}_{13}$. Structural, electronic and mechanical properties are obtained by using two sets of computations.

We first use classical simulations based on the force-field approach for an extensive search of compounds with interesting and related properties. DFT computations are carried out as a necessary confirmation of the properties revealed by the force-field method. This provides us with a further validation and transferability of the force field in determining the physicochemical properties of these types of compounds. For the classical simulations, the same setup and transferable force field reported in Ref. ${ }^{[12]}$ are adopted. DFT calculations are carried out with the aid of the CASTEP code. ${ }^{[13]}$ We employ various exchange-correlation functionals including the Perdew, Burke and Ernzerhof (PBE), Revised Perdew, Burke and Ernzerhof (RPBE), Perdew-Wang (PW91) and PBE with Wu-Cohen (WC) functionals over the generalized gradient approximation (GGA) ${ }^{[14-17]}$ The pseudo atomic functions for $\mathrm{Li}-2 \mathrm{~s}^{1}, \mathrm{O}-2 \mathrm{~s}^{2} 2 \mathrm{p}^{4}, \mathrm{Ti}-4 \mathrm{~s}^{2} 3 \mathrm{~d}^{2}$, and $\mathrm{Sn}-5 \mathrm{~s}^{2} 5 \mathrm{p}^{2}$ in their reciprocal representations are used. A plane wave cut-off energy of $550 \mathrm{eV}$ is adopted for the standard normconserving pseudopotentials. The choice of convergence threshold criteria is taken with a total energy change of $5 \times 10^{-6} \mathrm{eV}^{-1}$ atom ${ }^{-1}$ and maximum force, stress and atomic displacements of $10^{-2} \mathrm{eV} \AA^{-1}, 2 \times 10^{-2} \mathrm{GPa}$, and $5 \times 10^{-4} \AA$, respectively. A custom k-point grid of $6 \times 6 \times 2$ for $\mathrm{Li}_{2} \mathrm{M}_{6} \mathrm{O}_{13}$ $\left(\mathrm{M}=\mathrm{Ti}^{4+}\right.$ and $\left.\mathrm{Sn}^{4+}\right)$ and $5 \times 5 \times 2$ for $\mathrm{Li}_{2} \mathrm{SnO}_{3}$ is used to calculate the total and projected density of states in their primitive representation. A $\Gamma$-centered Monkhorst-Pack scheme ${ }^{[18]}$ was used during the geometry optimization and elastic constant calculations.

We first explore the lattice parameters of these compounds. Monoclinic $\mathrm{Li}_{2} \mathrm{SnO}_{3}(\mathrm{C} 2 / c)$ consists of layers of $\left[\mathrm{SnO}_{6}\right]$ combined with lithium ions forming planes without hybridization. In the conventional representation, two $\left[\mathrm{SnO}_{6}\right]$ layers are connected with three lithium planes. The reported lattice parameters of $a=5.2889 \AA, b=9.1872 \AA, c=10.026 \AA$, and $\beta=100.348^{\circ}$ are derived at $1000^{\circ} \mathrm{C} .{ }^{[19,20]}$

Figure 1 displays the structure of the $\mathrm{Li}_{2} \mathrm{Sn}_{6} \mathrm{O}_{13}$, adopted from the lattice structure of $\mathrm{Li}_{2} \mathrm{Ti}_{6} \mathrm{O}_{13}$, with $\mathrm{Ti}^{4+}$ replaced by $\mathrm{Sn}^{4+}$ (see Figure 2). Monoclinic $\mathrm{Li}_{2} \mathrm{Sn}_{6} \mathrm{O}_{13}$ could be synthetized by a doubly ion-exchange method as follows:

$\mathrm{Na}_{2} \mathrm{Ti}_{6} \mathrm{O}_{13}+\mathrm{Li}_{2} \mathrm{O} \rightarrow \mathrm{Li}_{2} \mathrm{Ti}_{6} \mathrm{O}_{13}+\mathrm{Na}_{2} \mathrm{O}$

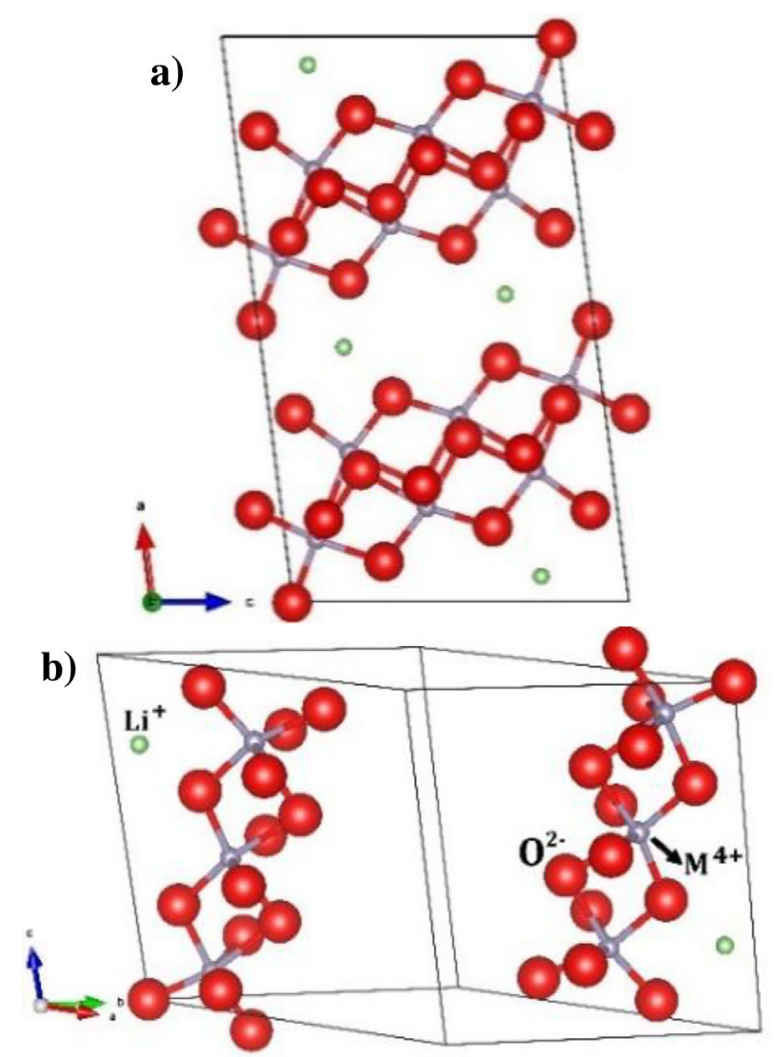

Figure 1. Conventional (a) and primitive (b) cells of $\mathrm{Li}_{2} \mathrm{M}_{6} \mathrm{O}_{13}$ in the $\mathrm{C} 2 / \mathrm{m}$ space group.

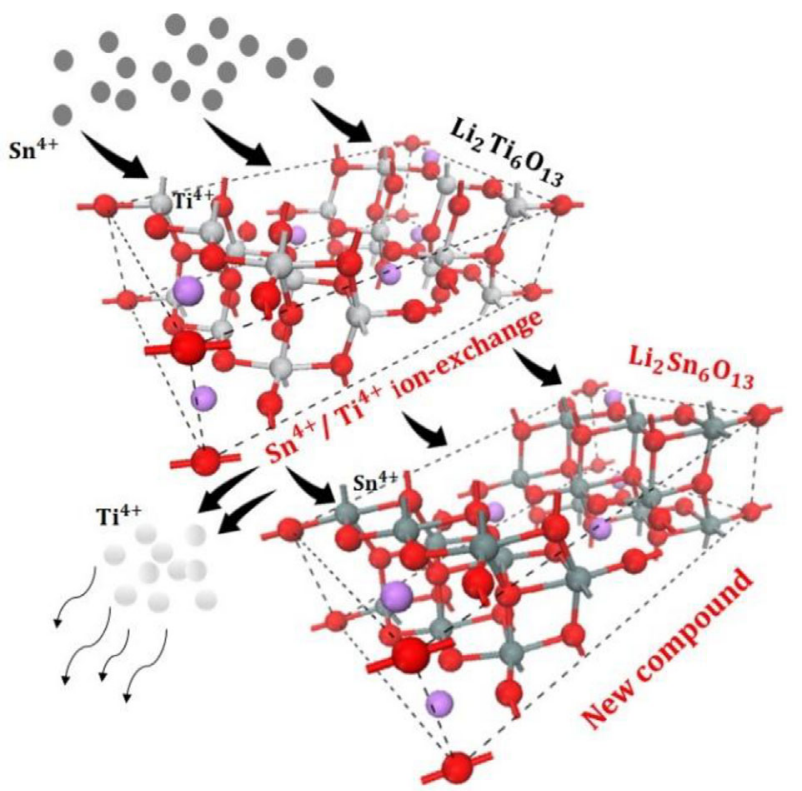

Figure 2. Schematic representation of $\mathrm{Ti}^{4+} / \mathrm{Sn}^{4+}$ ion exchange to form the $\mathrm{Li}_{2} \mathrm{Sn}_{6} \mathrm{O}_{13}$ from $\mathrm{Li}_{2} \mathrm{Ti}_{6} \mathrm{O}_{13}$. Grey, dark grey, red and blue balls represent $\mathrm{Ti}^{4+}, \mathrm{Sn}^{4+}, \mathrm{O}^{2-}$, and $\mathrm{Li}^{+}$ions, respectively. 
$\mathrm{Li}_{2} \mathrm{Ti}_{6} \mathrm{O}_{13}+6 \mathrm{SnO}_{2} \rightarrow \mathrm{Li}_{2} \mathrm{Sn}_{6} \mathrm{O}_{13}+6 \mathrm{TiO}_{2}$

where $\mathrm{Li}_{2} \mathrm{Ti}_{6} \mathrm{O}_{13}$ is an intermediate product of the $\mathrm{Na}^{+} / \mathrm{Li}^{+}$ion exchange reaction to obtain $\mathrm{Li}_{2} \mathrm{Sn}_{6} \mathrm{O}_{13}$.

The starting lattice parameters of $\mathrm{Li}_{2} \mathrm{Sn}_{6} \mathrm{O}_{13}$ are $a=15.307 \AA$, $b=3.747 \AA, c=9.140 \AA$, and $\beta=99.379^{\circ}$ in the $C 2 / m$ space group. ${ }^{[21]} \quad \mathrm{Li}_{2} \mathrm{M}_{6} \mathrm{O}_{13} \quad\left(\mathrm{M}=\mathrm{Ti}^{4+}\right.$ or $\left.\mathrm{Sn}^{4+}\right)$ consists of a $\left[\mathrm{M}_{6} \mathrm{O}_{13}\right]$ framework combined with $\mathrm{Li}^{+}$ions in square planar hybridization with oxygen ions. ${ }^{[19-21]}$ It is noteworthy that the $\mathrm{Ti}^{4+} / \mathrm{Sn}^{4+}$ ion exchange proposed in this study maintains the $\mathrm{Li}_{2} \mathrm{Ti}_{6} \mathrm{O}_{13}$ as the skeleton lattice structure to form the new $\mathrm{Li}_{2} \mathrm{Sn}_{6} \mathrm{O}_{13}$. In this scenario, $\mathrm{Li}^{+}$migration is not possible because all the $\mathrm{Li}^{+}$atomic positions are occupied.

The results of the lattice parameters obtained by geometry optimizations based on both DFT and force-field approaches are compiled in Table 1. During the geometry optimization with the force field, no negative frequencies are found in the structures studied. $^{[12]}$

In the case of the ideal $\mathrm{Li}_{2} \mathrm{Sn}_{6} \mathrm{O}_{13}$ structure, the GGA + RPBE functional provides the best fit to the perfect $\mathrm{Li}_{2} \mathrm{Ti}_{6} \mathrm{O}_{13}$ structure. The $a$ and $c$ lattice parameters increase, while $b$ and $\beta$ decrease by a lower percent with respect to the ideal (parent) $\mathrm{Li}_{2} \mathrm{Ti}_{6} \mathrm{O}_{13}$ structure. This is ascribed to the $\mathrm{Ti}^{4+}$ ion having a smaller ionic radius $(0.608 \AA)$ compared to that of $\mathrm{Sn}^{4+}$ $(0.69 \AA)$ in octahedral hybridization. ${ }^{[22]}$ The cell parameters of the $\mathrm{Li}_{2} \mathrm{Ti}_{6} \mathrm{O}_{13}$ structure calculated by DFT are consistent with the values determined by $\mathrm{X}$-ray, synchrotron and neutron powder diffraction. ${ }^{[9,10]}$ The GGA + WC functional yields the best fit to the perfect $\mathrm{Li}_{2} \mathrm{Ti}_{6} \mathrm{O}_{13}$ structure. For $\mathrm{Li}_{2} \mathrm{SnO}_{3}$, the GGA + RPBE functional also yields the best fit with respect to the cell parameters. ${ }^{[19,20]}$

\subsection{Mechanical Properties and Mechanical Stability}

Mechanical properties, together with analysis of the mechanical stability, are important keys to evaluate the feasibility of an unknown compound. Born and co-authors ${ }^{[23,24]}$ reported fundamental ideas to understand the conditions of mechanical stability of a crystalline structure. They established the main necessary and sufficient conditions of mechanical stability known as the Born criteria. ${ }^{[23]}$ Subsequently, many researchers have used alternative conditions. ${ }^{[25-28]}$

Mechanical stability is important for materials used, among others, in solid breeder ceramic compounds used in the International Thermoelectric Reactors (ITER), since during the tritium production it is important that the original structure should be preserved to ensure its breeding action and durability. ${ }^{[29,30]}$ The mechanical response of a crystal structure is described by the elastic (stiffness) constant matrix $\left(C_{i j}\right)$ defined as follows:

$C_{i j}=\frac{1}{\mathrm{~V}_{0}}\left(\frac{\partial^{2} E}{\partial \varepsilon_{i} \partial \varepsilon_{j}}\right)$

where $V_{0}$ represents the crystal equilibrium volume, $E$ its energy and $\varepsilon$ denotes a strain load. The Born criteria establishes that the energy, defined as:

$E=E_{0}+\frac{V_{0}}{2} \sum_{i, j=1}^{6} C_{i j} \varepsilon_{i} \varepsilon_{j}+O\left(\varepsilon^{3}\right)$

for an arbitrary homogeneous deformation loaded by an infinitesimal strain, is always positive, ${ }^{[23,24]}$ where the 0 subscript in Eq. (4) refers to the equilibrium state of the crystal.

Table 1. Cell parameters obtained by DFT using different exchange-correlation functionals, including static simulations employing the force-field parameters. Deviations (in \%) with respect to experimental values are listed in brackets.

\begin{tabular}{|c|c|c|c|c|c|c|}
\hline \multicolumn{7}{|c|}{$\mathrm{Li}_{2} \mathrm{SnO}_{3}(\mathrm{C} 2 / c)$} \\
\hline & PBE & RPBE & PW91 & WC & Ref. [9] & $\mathrm{FF}$ \\
\hline$a(\stackrel{\circ}{A})$ & $5.03(-4.94)$ & $5.04(-4.8)$ & $5.02(-5.0)$ & $5.02(-5.16)$ & 5.29 & $5.19(-1.85)$ \\
\hline$b(\stackrel{\circ}{A})$ & $8.72(-4.79)$ & $8.74(-4.6)$ & $8.71(-4.9)$ & $8.70(-5.0)$ & 9.16 & $9.01(-1.65)$ \\
\hline$c(\stackrel{\circ}{\mathrm{A}})$ & $9.65(-3.11)$ & $9.70(-2.59)$ & $9.63(-3.28)$ & $9.58(-3.8)$ & 10.0 & $9.59(-3.7)$ \\
\hline$\beta\left({ }^{\circ}\right)$ & $100.13(-0.22)$ & $100.17(-0.18)$ & $99.97(-0.37)$ & $100.12(-0.23)$ & 100.35 & $100.32(-0.03)$ \\
\hline \multicolumn{7}{|c|}{$\mathrm{Li}_{2} \mathrm{Sn}_{6} \mathrm{O}_{13} \quad(\mathrm{C} 2 / m)$} \\
\hline & PBE & RPBE & PW91 & WC & Ref. [1]] & FF \\
\hline$a(\stackrel{\circ}{A})$ & $14.76(4)$ & $14.76(-3.57)$ & $14.75(-3.64)$ & $14.75(-3.67)$ & 15.31 & $15.99(+4.49)$ \\
\hline$b(\stackrel{\circ}{A})$ & $3.97(+5.88)$ & $3.97(+6.0)$ & $3.96(+5.72)$ & $3.96(+5.8)$ & 3.75 & $3.83(+2.1)$ \\
\hline$c(\stackrel{\mathrm{A}}{)}$ & $8.79(-3.87)$ & $8.82(-3.54)$ & $8.78(-3.94)$ & $8.76(-4.2)$ & 9.14 & $9.43(+3.2)$ \\
\hline$\beta\left({ }^{\circ}\right)$ & $98.75(-0.63)$ & $99.06(-0.33)$ & $98.71(-0.67)$ & $98.42(-0.97)$ & 99.38 & $97.21(-2.18)$ \\
\hline \multicolumn{7}{|c|}{$\mathrm{Li}_{2} \mathrm{Ti}_{6} \mathrm{O}_{13}(\mathrm{C} 2 / m)$} \\
\hline & PBE & RPBE & PW91 & WC & Ref. [11] & $\mathrm{FF}$ \\
\hline$a(\stackrel{\circ}{\mathrm{A}})$ & $15.57(+1.71)$ & $15.60(+1.88)$ & $15.55(+1.62)$ & $15.53(+1.48)$ & 15.31 & $15.59(+1.7)$ \\
\hline$b(\stackrel{\circ}{A})$ & $3.77(+0.72)$ & $3.79(+1.1)$ & $3.77(+0.72)$ & $3.77(+0.51)$ & 3.75 & $3.74(-0.40)$ \\
\hline$c(\stackrel{\circ}{\mathrm{A}})$ & $9.26(+1.22)$ & $9.29(+1.60)$ & $9.24(+1.14)$ & $9.20(+0.61)$ & 9.14 & $9.18(+0.4)$ \\
\hline$\beta\left({ }^{\circ}\right)$ & $99.47(+0.09)$ & $99.68(+0.30)$ & $99.40(+0.03)$ & $99.24(-0.14)$ & 99.38 & $97.45(-1.94)$ \\
\hline
\end{tabular}


This criterion is equivalent to the fact that the $C_{i j}$ matrix should be positive definite, which means that all its eigenvalues must be positive. Some authors have used other criteria, such as the Fedorov criteria, where only the diagonal elements of $C_{i j}$ must be positive. Such a condition turns out to be necessary but not sufficient. ${ }^{[2]}$ In such cases, the Fedorov criteria ${ }^{[27,28]}$ leads to incorrect conclusions concerning the mechanical stability of systems, such as MOF-74 materials with $\mathrm{CH}_{4}$ molecules. ${ }^{[25]}$

The $C_{i j}$ matrix of the new $\mathrm{Li}_{2} \mathrm{Sn}_{6} \mathrm{O}_{13}$ compound, obtained from DFT calculations, is:

$C_{i j}=\left(\begin{array}{cccccc}241.28 & 19.72 & 122.83 & 0 & 24.31 & 0 \\ 19.72 & 264.22 & 63.25 & 0 & 0.43 & 0 \\ 122.83 & 63.25 & 300.27 & 0 & 71.65 & 0 \\ 0 & 0 & 0 & 74.35 & 0 & 13.36 \\ 24.31 & 0.43 & 71.65 & 0 & 72.38 & 0 \\ 0 & 0 & 0 & 13.36 & 0 & 28.45\end{array}\right)$

The eigenvalues $\lambda_{i}$ of $C_{i j}(i, j=1,2, \ldots, 6)$ are obtained by $\operatorname{DET}\left(\mathrm{C}_{i j}-\lambda_{i} I_{i j}\right)=0$, where DET denotes the determinantal and $I_{i j}$ the unity matrix of the same size as $C_{i j}$. The calculated $\lambda_{i}$ are: $\lambda_{1}=24.85, \lambda_{2}=49.31, \lambda_{3}=77.95, \lambda_{4}=147.63, \lambda_{5}=246.85$ and $\lambda_{6}=434.36 \mathrm{GPa}$. All the values are positive and thus confirm the mechanical stability of $\mathrm{Li}_{2} \mathrm{Sn}_{6} \mathrm{O}_{13}$. Similar results can be obtained by using the $C_{i j}$ components resulting from the force-field approach. Other equivalent necessary and sufficient conditions can be used and derived from the properties of the positive matrix, with the aid of other linear algebra subroutines. ${ }^{[27]}$ The obtained elastic constant components for $\mathrm{Li}_{2} \mathrm{Ti}_{6} \mathrm{O}_{13}$ and $\mathrm{Li}_{2} \mathrm{SnO}_{3}$ are given in Table 2. For monoclinic structures, there are 13 independent constants along the plane $y=0$, together with 12 relations to satisfy the Born criteria. ${ }^{[23,24]}$ The $C_{i j}$ values collected in Table 2 reveal that the stability conditions are satisfied. To our knowledge, no experimental data exist for a comparison of the values of $C_{i j}$ for $\mathrm{Li}_{2} \mathrm{Ti}_{6} \mathrm{O}_{13}$ and $\mathrm{Li}_{2} \mathrm{SnO}_{3}$.

The force-field method provides us with expectation values of the mechanical properties in the case of $\mathrm{Li}_{2} \mathrm{Ti}_{6} \mathrm{O}_{13}$. The negative value of $\mathrm{C}_{15}$ for $\mathrm{Li}_{2} \mathrm{SnO}_{3}$ is analogous to that of the $\mathrm{Li}_{2} \mathrm{TiO}_{3}$ structure reported previously. ${ }^{[31]}$ In our previous work, the values of $C_{i j}$ for $\mathrm{Li}_{2} \mathrm{SnO}_{3}$ were also calculated via both DFTand the forcefield methods. ${ }^{[12]}$ The small discrepancies in the $C_{i j}$ values obtained using DFT are attributed to the use of different exchange-correlation functionals.

Other standard parameters can also be determined. The bulk $(B)$, shear $(G)$ and Young's moduli $(E)$ are then calculated after geometry optimization. The relevant magnitudes are compiled in Table 3. To our knowledge, previous studies based on DFT computations or experimental results did not report on the exploration of mechanical properties of these structures.

However, for $\mathrm{Li}_{2} \mathrm{SnO}_{3}$, the difference in the values calculated by DFT and force-field methods can be attributed to the contraction in the $c$ axis. Both $\mathrm{Li}_{2} \mathrm{SnO}_{3}$ and $\mathrm{Li}_{2} \mathrm{TiO}_{3}$ exhibit a similar $c$-axis contraction in the $C 2 / c$ space group. ${ }^{[31]}$ In general, the calculated values are consistent for this type of structure.

In the case of the unknown $\mathrm{Li}_{2} \mathrm{Sn}_{6} \mathrm{O}_{13}$ structure, its values for mechanical properties obtained by both DFT and force-field
Table 2. Elastic constant tensor components (in $\mathrm{GPa}$ ) of $\mathrm{Li}_{2} \mathrm{SnO}_{3}$, $\mathrm{Li}_{2} \mathrm{Ti}_{6} \mathrm{O}_{13}$, and $\mathrm{Li}_{2} \mathrm{Sn}_{6} \mathrm{O}_{13}$ compounds, obtained upon full geometry optimization using the force field and/or DFT calculations.

\begin{tabular}{|c|c|c|c|c|c|}
\hline & \multicolumn{2}{|c|}{$\mathrm{Li}_{2} \mathrm{SnO}_{3}$} & \multirow{2}{*}{$\frac{\mathrm{Li}_{2} \mathrm{Ti}_{6} \mathrm{O}_{13}}{\mathrm{FF}}$} & \multicolumn{2}{|c|}{$\mathrm{Li}_{2} \mathrm{Sn}_{6} \mathrm{O}_{13}$} \\
\hline & DFT & $\mathrm{FF}$ & & DFT & $\mathrm{FF}$ \\
\hline$C_{11}$ & 267.90 & 196.22 & 138.11 & 241.28 & 116.49 \\
\hline$C_{12}$ & 98.68 & 73.76 & 48.75 & 19.72 & 36.58 \\
\hline$C_{13}$ & 39.40 & 36.48 & 83.70 & 122.83 & 81.61 \\
\hline$C_{15}$ & -62.84 & -11.80 & 14.40 & 24.31 & 7.23 \\
\hline$C_{22}$ & 330.0 & 190.02 & 240.43 & 264.22 & 202.58 \\
\hline$C_{23}$ & 23.12 & 36.30 & 89.37 & 63.25 & 76.57 \\
\hline$C_{25}$ & 19.50 & 16.42 & 4.02 & 0.426 & 1.08 \\
\hline$C_{33}$ & 213.71 & 108.09 & 208.83 & 300.27 & 180.51 \\
\hline$C_{35}$ & 15.67 & 2.09 & 17.56 & 71.65 & 15.88 \\
\hline$C_{44}$ & 36.09 & 29.16 & 33.93 & 74.35 & 25.25 \\
\hline$C_{46}$ & 16.23 & 15.82 & 1.59 & 13.36 & 1.50 \\
\hline$C_{55}$ & 59.33 & 29.66 & 51.25 & 72.38 & 44.89 \\
\hline$C_{66}$ & 122.45 & 60.02 & 5.14 & 28.45 & 4.66 \\
\hline
\end{tabular}

approaches can best be considered as the lower and upper limits of these quantities, with the hope that their experimental confirmation could be a subject for future studies.

The ductility and brittleness criteria are calculated by the Pugh formula $B / G,^{[3,32]}$ including the degree of elastic anisotropy defined as:

$F_{\mathrm{B}}=\frac{B_{\text {Voigt }}-B_{\text {Reuss }}}{B_{\text {Voigt }}+B_{\text {Reuss }}} ; \quad F_{\mathrm{G}}=\frac{G_{\text {Voigt }}-G_{\text {Reuss }}}{G_{\text {Voigt }}+G_{\text {Reuss }}}$.

All the values of $B / G$ are greater than 1.75 , which reveals that all the structures considered behave as brittleness materials. ${ }^{[32]}$ It can be noted that all the structures exhibit a very low bulk and shear anisotropy. Both compounds $\mathrm{Li}_{2} \mathrm{Sn}_{6} \mathrm{O}_{13}$ and $\mathrm{Li}_{2} \mathrm{Ti}_{6} \mathrm{O}_{13}$ have a similar degree in anisotropy with respect to the volume and shape change. $\mathrm{Li}_{2} \mathrm{SnO}_{3}$ is more anisotropic with respect to the shape change than for the volume change. $\mathrm{Li}_{2} \mathrm{SnO}_{3}$ has thus the largest value of $F_{\mathrm{B}} / F_{\mathrm{G}}$, followed by $\mathrm{Li}_{2} \mathrm{Sn}_{6} \mathrm{O}_{13}$ and $\mathrm{Li}_{2} \mathrm{Ti}_{6} \mathrm{O}_{13}$. Thus, $\mathrm{Li}_{2} \mathrm{SnO}_{3}$ is the most balanced material in elastic isotropy.

$\mathrm{Li}_{2} \mathrm{Sn}_{6} \mathrm{O}_{13}$ is more elastically isotropic and more resistant regarding volume changes than $\mathrm{Li}_{2} \mathrm{Ti}_{6} \mathrm{O}_{13}$.

The elastic isotropy/anisotropy is not only significant for solid breeder materials, but it is also very important to determine the nature of microcrack sources and propagations in polycrystalline materials.

These results reveal the general mechanical behavior of the essential lithium-based materials that can be used as breeder and in $\mathrm{Li}^{+}$-ion batteries.

\subsection{Thermodynamic Stability}

Having confirmed the mechanical stability of $\mathrm{Li}_{2} \mathrm{Sn}_{6} \mathrm{O}_{13}$, it is highly desirable to further examine its thermodynamic stability by evaluating its standard molar formation enthalpy. 
Table 3. Bulk $(B)$, Shear $(G)$, and Young's $(E)$ moduli and anisotropy factors of $\mathrm{Li}_{2} \mathrm{SnO}_{3}, \mathrm{Li}_{2} \mathrm{Sn}_{6} \mathrm{O}_{13}$, and $\mathrm{Li}_{2} \mathrm{Ti}_{6} \mathrm{O}_{13}$ (bold values are obtained by DFT).

\begin{tabular}{|c|c|c|c|c|c|c|c|c|c|}
\hline \multirow[b]{2}{*}{ Force field } & \multicolumn{3}{|c|}{$B(\mathrm{GPa})$} & \multicolumn{3}{|c|}{$G(\mathrm{GPa})$} & \multicolumn{3}{|c|}{$E(\mathrm{GPa})$} \\
\hline & Reuss & Voigt & Hill & Reuss & Voigt & Hill & $\mathrm{x}$ & y & z \\
\hline $\mathrm{Li}_{2} \mathrm{SnO}_{3}$ & 77.41 & 87.49 & 82.45 & 36.63 & 46.95 & 41.79 & 151.11 & 143.50 & 98.10 \\
\hline $\mathrm{Li}_{2} \mathrm{Sn}_{6} \mathrm{O}_{13}$ & 88.63 & 98.79 & 93.71 & 15.12 & 35.28 & 25.20 & 79.57 & 169.31 & 106.96 \\
\hline \multirow[t]{2}{*}{$\mathrm{Li}_{2} \mathrm{Ti}_{6} \mathrm{O}_{13}$} & 102.78 & 114.56 & 108.67 & 17.55 & 42.44 & 30.0 & 102.58 & 200.19 & 140.41 \\
\hline & \multicolumn{3}{|c|}{$B(\mathrm{GPa})$} & \multicolumn{3}{|c|}{$G(\mathrm{GPa})$} & \multicolumn{3}{|c|}{$E(\mathrm{GPa})$} \\
\hline DFT & Reuss & Voigt & Hill & Reuss & Voigt & Hill & $\mathrm{x}$ & $y$ & z \\
\hline $\mathrm{Li}_{2} \mathrm{SnO}_{3}$ & 117.54 & 126.01 & 121.78 & 54.04 & 86.94 & 70.49 & 145.66 & 251.76 & 193.08 \\
\hline $\mathrm{Li}_{2} \mathrm{Sn}_{6} \mathrm{O}_{13}$ & 120.03 & 135.26 & 127.64 & 52.13 & 75.03 & 63.58 & 190.36 & 246.71 & 176.18 \\
\hline$\underline{\mathrm{Li}_{2} \mathrm{Ti}_{6} \mathrm{O}_{13}}$ & \multicolumn{3}{|c|}{-} & \multicolumn{3}{|c|}{-} & \multicolumn{3}{|c|}{-} \\
\hline \multicolumn{10}{|c|}{ Values of $B / G, F_{\mathrm{B}}, F_{\mathrm{G}}$, and $F_{\mathrm{B}} / F_{\mathrm{C}}$} \\
\hline & \multicolumn{4}{|c|}{$B / G$} & & \multicolumn{4}{|c|}{ Anisotropy factors } \\
\hline Compound & \multicolumn{2}{|c|}{ Reuss } & Voigt & \multicolumn{2}{|l|}{ Hill } & $F_{\mathrm{B}}$ & \multicolumn{2}{|c|}{$F_{\mathrm{G}}$} & $F_{\mathrm{B}} / F_{\mathrm{C}}$ \\
\hline $\mathrm{Li}_{2} \mathrm{SnO}_{3}$ & \multicolumn{2}{|c|}{$2.11 / 2.18$} & $1.86 / 1.45$ & \multicolumn{2}{|l|}{$1.97 / 1.73$} & $0.061 / 0.035$ & \multicolumn{2}{|c|}{$0.123 / 0.233$} & $0.50 / 0.149$ \\
\hline $\mathrm{Li}_{2} \mathrm{Sn}_{6} \mathrm{O}_{13}$ & \multicolumn{2}{|c|}{$5.86(2) / 2.30$} & $2.80 / 1.80$ & \multicolumn{2}{|l|}{$3.72 / 2.01$} & $0.054 / 0.060$ & \multicolumn{2}{|c|}{$0.400 / 0.180$} & $0.136 / 0.331$ \\
\hline $\mathrm{Li}_{2} \mathrm{Ti}_{6} \mathrm{O}_{13}$ & \multicolumn{2}{|c|}{$5.85(6)$} & 2.70 & \multicolumn{2}{|l|}{3.62} & 0.054 & \multicolumn{2}{|c|}{0.415} & 0.131 \\
\hline
\end{tabular}

The procedure to obtain the standard molar enthalpy is well established. ${ }^{[33,34]}$ Considering the thermodynamic cycle to form the $\mathrm{Li}_{2} \mathrm{M}_{6} \mathrm{O}_{13}\left(\mathrm{M}=\mathrm{Ti}^{4+}\right.$ or $\left.\mathrm{Sn}^{4+}\right)$ compounds:

$\mathrm{Li}_{2} \mathrm{O}(\mathrm{s})+6 \mathrm{MO}_{2}(\mathrm{~s}) \rightarrow \mathrm{Li}_{2} \mathrm{M}_{6} \mathrm{O}_{13}(\mathrm{~s})$

the standard molar formation enthalpy $\left(\Delta_{\mathrm{r}} H_{\mathrm{m}}\right)$ can be estimated by:

$\Delta_{\mathrm{r}} H_{\mathrm{m}}=\Delta_{\mathrm{f}} H_{\mathrm{m}}\left(\mathrm{Li}_{2} \mathrm{M}_{6} \mathrm{O}_{13}\right)-\Delta_{\mathrm{f}} H_{\mathrm{m}}\left(\mathrm{Li}_{2} \mathrm{O}\right)-6 \Delta_{\mathrm{f}} H_{\mathrm{m}}\left(\mathrm{MO}_{2}\right)$

which can be written in terms of total energy (E) as follows:

$\Delta_{\mathrm{r}} \mathrm{H}_{\mathrm{m}}=\mathrm{E}\left(\mathrm{Li}_{2} \mathrm{M}_{6} \mathrm{O}_{13}\right)-\mathrm{E}\left(\mathrm{Li}_{2} \mathrm{O}\right)-6 \mathrm{E}\left(\mathrm{MO}_{2}\right)$

where the values of the total energy of the considered oxide compounds were taken from the results of the geometry optimization based on DFT calculations with the same setup used previously. Finally, the standard molar formation enthalpy of $\mathrm{Li}_{2} \mathrm{Sn}_{6} \mathrm{O}_{13}$ and $\mathrm{Li}_{2} \mathrm{Ti}_{6} \mathrm{O}_{13}$ can be obtained by:

$\Delta_{\mathrm{r}} H_{\mathrm{m}}\left(\mathrm{Li}_{2} \mathrm{M}_{6} \mathrm{O}_{13}\right)=\Delta_{\mathrm{r}} H_{\mathrm{m}}+\Delta_{\mathrm{f}} H_{\mathrm{m}}\left(\mathrm{Li}_{2} \mathrm{O}\right)+6 \Delta_{\mathrm{f}} H_{\mathrm{m}}\left(\mathrm{MO}_{2}\right)$

The total energies under the GGA + RPBE approximation are $-820.06,-1915.40,-1914.87,-12387.25$, and $-12382.04 \mathrm{eV}$ for $\mathrm{Li}_{2} \mathrm{O}$, rutile $\mathrm{TiO}_{2}, \mathrm{SnO}_{2}, \mathrm{Li}_{2} \mathrm{Ti}_{6} \mathrm{O}_{13}$, and $\mathrm{Li}_{2} \mathrm{Sn}_{6} \mathrm{O}_{13}$, respectively.

With the available information of the standard molar formation enthalpy of $\mathrm{Li}_{2} \mathrm{O}$, rutile $\mathrm{TiO}_{2}$, and $\mathrm{SnO}_{2}$ taken from Refs. ${ }^{[35-37]}$, the values of the standard molar enthalpy and the standard molar formation enthalpy of $\mathrm{Li}_{2} \mathrm{Sn}_{6} \mathrm{O}_{13}$ and $\mathrm{Li}_{2} \mathrm{Ti}_{6} \mathrm{O}_{13}$ are obtained and presented in Table 4 . To our knowledge, no data for the standard molar formation enthalpy of $\mathrm{Li}_{2} \mathrm{Ti}_{6} \mathrm{O}_{13}$ was previously reported.

The thermodynamic stability of the parent structure to form the $\mathrm{Li}_{2} \mathrm{Ti}_{6} \mathrm{O}_{13}$ structure via $\mathrm{Na}^{+} / \mathrm{Li}^{+}$ion exchange was previously studied. ${ }^{[35]}$ Considering the thermodynamic data of $\mathrm{Na}_{2} \mathrm{Ti}_{6} \mathrm{O}_{13}$ $\left(\Delta_{\mathrm{f}} H_{\mathrm{m}}=-6277.9 \pm 6.5 \mathrm{~kJ} \mathrm{~mol}^{-1[35]}\right)$ and $\mathrm{K}_{2} \mathrm{Ti}_{6} \mathrm{O}_{13} \quad\left(\Delta_{\mathrm{f}} H_{\mathrm{m}}=\right.$ $\left.-6035 \mathrm{~kJ} \mathrm{~mol}^{-1[38]}\right)$, the values of $\Delta_{\mathrm{f}} H_{\mathrm{m}}$ of $\mathrm{Li}_{2} \mathrm{M}_{6} \mathrm{O}_{13}\left(\mathrm{M}=\mathrm{Ti}^{4+}\right.$ or $\mathrm{Sn}^{4+}$ ) agree with these structural types. Hence, it can be concluded that both $\mathrm{Li}_{2} \mathrm{Ti}_{6} \mathrm{O}_{13}$ and $\mathrm{Li}_{2} \mathrm{Sn}_{6} \mathrm{O}_{13}$ have high thermodynamic stability.

To further explore the thermodynamic properties of the $\mathrm{Li}_{2} \mathrm{M}_{6} \mathrm{O}_{13}$ compounds, the energetic cost required for the inclusion-extraction of its individual constituent elements are calculated using the hypothetical reactions:

$\mathrm{Li}_{4} \mathrm{M}_{12} \mathrm{O}_{26} \rightarrow \mathrm{Li}_{3} \mathrm{M}_{12} \mathrm{O}_{26}+\mathrm{Li}$

$\mathrm{Li}_{4} \mathrm{M}_{12} \mathrm{O}_{26} \rightarrow \mathrm{Li}_{4} \mathrm{M}_{11} \mathrm{O}_{26}+\mathrm{M}$

$\mathrm{Li}_{4} \mathrm{M}_{12} \mathrm{O}_{26} \rightarrow \mathrm{Li}_{4} \mathrm{M}_{12} \mathrm{O}_{25}+\mathrm{O}$

Note that the stoichiometry in Eqs. (11) to (13) of $\mathrm{Li}_{2} \mathrm{M}_{6} \mathrm{O}_{13}$ is augmented by 2 because the $\mathrm{Z}$ formula unit is 2 for the $\mathrm{A}_{2} \mathrm{M}_{6} \mathrm{O}_{13}$ unit cells. ${ }^{[10,39]}$ The procedure exposed here was also used satisfactorily in Ref. 40 to elucidate the energetics of $\mathrm{Li}_{2} \mathrm{TiO}_{3}$.

Table 4. Standard molar $\Delta_{\mathrm{r}} H_{\mathrm{m}}$ and formation $\Delta_{\mathrm{f}} H_{\mathrm{m}}$ enthalpy of $\mathrm{Li}_{2} \mathrm{Ti}_{6} \mathrm{O}_{13}$ and $\mathrm{Li}_{2} \mathrm{Sn}_{6} \mathrm{O}^{13}$ (in k/ mol${ }^{-1}$ ).

\begin{tabular}{lcc}
\hline & $\mathrm{Li}_{2} \mathrm{Ti}_{6} \mathrm{O}_{13}$ & $\mathrm{Li}_{2} \mathrm{Sn}_{6} \mathrm{O}_{13}$ \\
\hline$\Delta_{\mathrm{r}} H_{\mathrm{m}}$ & -7217.55 & -7022.18 \\
$\Delta_{\mathrm{f}} H_{\mathrm{m}}$ & $-6740.14 \dagger$ & $-5552.55^{\mathrm{a})}$ \\
\hline
\end{tabular}

${ }^{a)}$ Referred to the primitive cell, for the conventional representation the values are the doublet. 
To obtain the total energy by DFT calculations, a $1 \times 2 \times 1$ supercell is used for the non-stoichiometric reactants. The reaction energy is then obtained as:

$\Delta E=E\left(\mathrm{Li}_{4} \mathrm{M}_{12} \mathrm{O}_{26}\right)-\left[E(\mathrm{Li})+E\left(\mathrm{Li}_{3} \mathrm{M}_{12} \mathrm{O}_{26}\right)\right]$

$\Delta E=E\left(\mathrm{Li}_{4} \mathrm{M}_{12} \mathrm{O}_{26}\right)-\left[E(\mathrm{M})+E\left(\mathrm{Li}_{4} \mathrm{M}_{11} \mathrm{O}_{26}\right)\right]$

$\Delta E=E\left(\mathrm{Li}_{4} \mathrm{M}_{12} \mathrm{O}_{26}\right)-\left[E(\mathrm{O})+E\left(\mathrm{Li}_{4} \mathrm{M}_{12} \mathrm{O}_{25}\right)\right]$

for reactions (11) to (13), respectively. $\Delta E$ denotes the reaction energy and $E(X)$ the total energy of the compound $X$. Table 5 compiles the results of $\Delta E$ in different energy units for comparison.

As shown in Table 5 , the energy needed to remove a $\mathrm{Li}^{+}$ion or cleave a $\mathrm{Li}-\mathrm{X}$ bond in $\mathrm{Li}_{2} \mathrm{Sn}_{6} \mathrm{O}_{13}$ is comparable with the value obtained for $\mathrm{Li}_{2} \mathrm{Ti}_{6} \mathrm{O}_{13}$. This means that, if the new compound can be synthetized, it should be as stable as its hexatitanate counterpart. The tritium release in the ITER depends on the $\Delta E(\mathrm{Li})$ value during the reaction of ${ }^{6} \mathrm{Li}$ with neutrons. ${ }^{[29,30]}$ In the ITER, the liberation/production of lithium/tritium ions will take place at the same range of temperature in $\mathrm{Li}_{2} \mathrm{Sn}_{6} \mathrm{O}_{13}$ and $\mathrm{Li}_{2} \mathrm{Ti}_{6} \mathrm{O}_{13}$ compounds due to the small difference in $\Delta E$ of $\approx 11 \mathrm{kcal} \mathrm{mol}^{-1}$ between both compounds. The values are lower compared with $\mathrm{Li}_{2} \mathrm{TiO}_{3}$, which is the best candidate for use in the ITER. $^{[40]}$

Furthermore, the $\Delta E(\mathrm{Li})$ values are the lowest in both $\mathrm{Li}_{2} \mathrm{Sn}_{6} \mathrm{O}_{13}$ and $\mathrm{Li}_{2} \mathrm{Ti}_{6} \mathrm{O}_{13}$, revealing that $\mathrm{Li}^{+}$is the most mobile ion and responsible for the transport properties in these structures. From the point of view of the values of $\Delta E(\mathrm{M})$ and $\Delta E(\mathrm{O})$, the $\mathrm{Li}_{2} \mathrm{Sn}_{6} \mathrm{O}_{13}$ compound is quite comparable to $\mathrm{Li}_{2} \mathrm{Ti}_{6} \mathrm{O}_{13}$.

The values of $\Delta E(\mathrm{Sn})$ and $\Delta E(\mathrm{Ti})$ have a relatively small difference of $17 \mathrm{kcal} \mathrm{mol}^{-1}$ and are the second lowest values of reaction energy, followed by a small difference of $14 \mathrm{kcal} \mathrm{mol}^{-1}$ of $\Delta E(\mathrm{O})$ between both compounds, revealing the possibility of $\mathrm{Ti}^{4+} / \mathrm{Sn}^{4+}$ ion exchange. Compiling these results and the values of the standard molar formation enthalpy, both $\mathrm{Li}_{2} \mathrm{M}_{6} \mathrm{O}_{13}$ compounds appear to be thermodynamically stable.

Table 5. Reaction energy $(\Delta E)$ of $\mathrm{Li}_{2} \mathrm{Ti}_{6} \mathrm{O}_{13}$ and $\mathrm{Li}_{2} \mathrm{Sn}_{6} \mathrm{O}_{13}$.

\begin{tabular}{|c|c|c|c|}
\hline \multirow[b]{3}{*}{ Reaction } & \multicolumn{3}{|c|}{$\mathrm{Li}_{2} \mathrm{Sn}_{6} \mathrm{O}_{13}$} \\
\hline & $\mathrm{Li}$ & $\mathrm{Sn}$ & 0 \\
\hline & $\overline{\mathrm{LiSn}_{6} \mathrm{O}_{13}}$ & $\overline{\mathrm{Li}_{2} \mathrm{Sn}_{5} \mathrm{O}_{13}}$ & $\overline{\mathrm{Li}_{2} \mathrm{Sn}_{6} \mathrm{O}_{12}}$ \\
\hline$E(X)\left[\mathrm{eV}\right.$ atom $\left.^{-1}\right]$ & -298.33 & -297.14 & -293.12 \\
\hline$\Delta E\left[\mathrm{kcal} \mathrm{mol}^{-1}\right]$ & 229.81 & 774.83 & 1045.74 \\
\hline \multirow[t]{3}{*}{$\Delta E\left[\mathrm{eV}\right.$ atom $\left.^{-1}\right]$} & 6.41 & & \\
\hline & \multicolumn{3}{|c|}{$\mathrm{Li}_{2} \mathrm{Ti}_{6} \mathrm{O}_{13}$} \\
\hline & $\mathrm{Li}$ & $\mathrm{Ti}$ & O \\
\hline Reaction & $\mathrm{LiTi}_{6} \mathrm{O}_{13}$ & $\mathrm{Li}_{2} \mathrm{Ti}_{5} \mathrm{O}_{13}$ & $\mathrm{Li}_{2} \mathrm{Ti}_{6} \mathrm{O}_{12}$ \\
\hline$E(X)\left[\mathrm{eV}\right.$ atom $\left.^{-1}\right]$ & -298.64 & -297.44 & -293.58 \\
\hline$\Delta E\left[\mathrm{kcal} \mathrm{mol}^{-1}\right]$ & 240.43 & 791.69 & 1059.72 \\
\hline$\Delta E\left[\mathrm{eV}\right.$ atom $\left.^{-1}\right]$ & 6.87 & & \\
\hline
\end{tabular}

\subsection{Electronic Structure}

The electronic band structures of $\mathrm{Li}_{2} \mathrm{Sn}_{6} \mathrm{O}_{13}, \mathrm{Li}_{2} \mathrm{Ti}_{6} \mathrm{O}_{13}$, and $\mathrm{Li}_{2} \mathrm{SnO}_{3}$ are obtained using the calibration by DFT calculations with the GGA + RPBE functional. The total and projected density of states and band structures are obtained with the interpolation integration method with a broadening factor of $0.05 \mathrm{eV}$.

Figure 3 displays the band structures of $\mathrm{Li}_{2} \mathrm{Ti}_{6} \mathrm{O}_{13}, \mathrm{Li}_{2} \mathrm{Sn}_{6} \mathrm{O}_{13}$, and $\mathrm{Li}_{2} \mathrm{SnO}_{3}$ at their equilibrium ground state. $\mathrm{Li}_{2} \mathrm{SnO}_{3}$ exhibits an insulating character considering the large band gap energies. $\mathrm{Li}_{2} \mathrm{Sn}_{6} \mathrm{O}_{13}$ has a larger band gap energy in the valence band boundary. The calculated band structure of $\mathrm{Li}_{2} \mathrm{SnO}_{3}$ also shows an indirect gap from the A point at the valence band maximum to the $\Gamma$ point $(G)$ at the conduction band minimum, with a calculated value of $4.5 \mathrm{eV}$. In view of the usual underestimation of DFT + GGA calculated band gap, the calculated value agrees with the estimated value $(\approx 3 \mathrm{eV})$ from the optical diffuse reflectance spectrum reported for $\mathrm{Li}_{2} \mathrm{SnO}_{3} \cdot{ }^{[39]} \mathrm{Li}_{2} \mathrm{Sn}_{6} \mathrm{O}_{13}$ also has an indirect gap from the Z-point at the valence band maximum
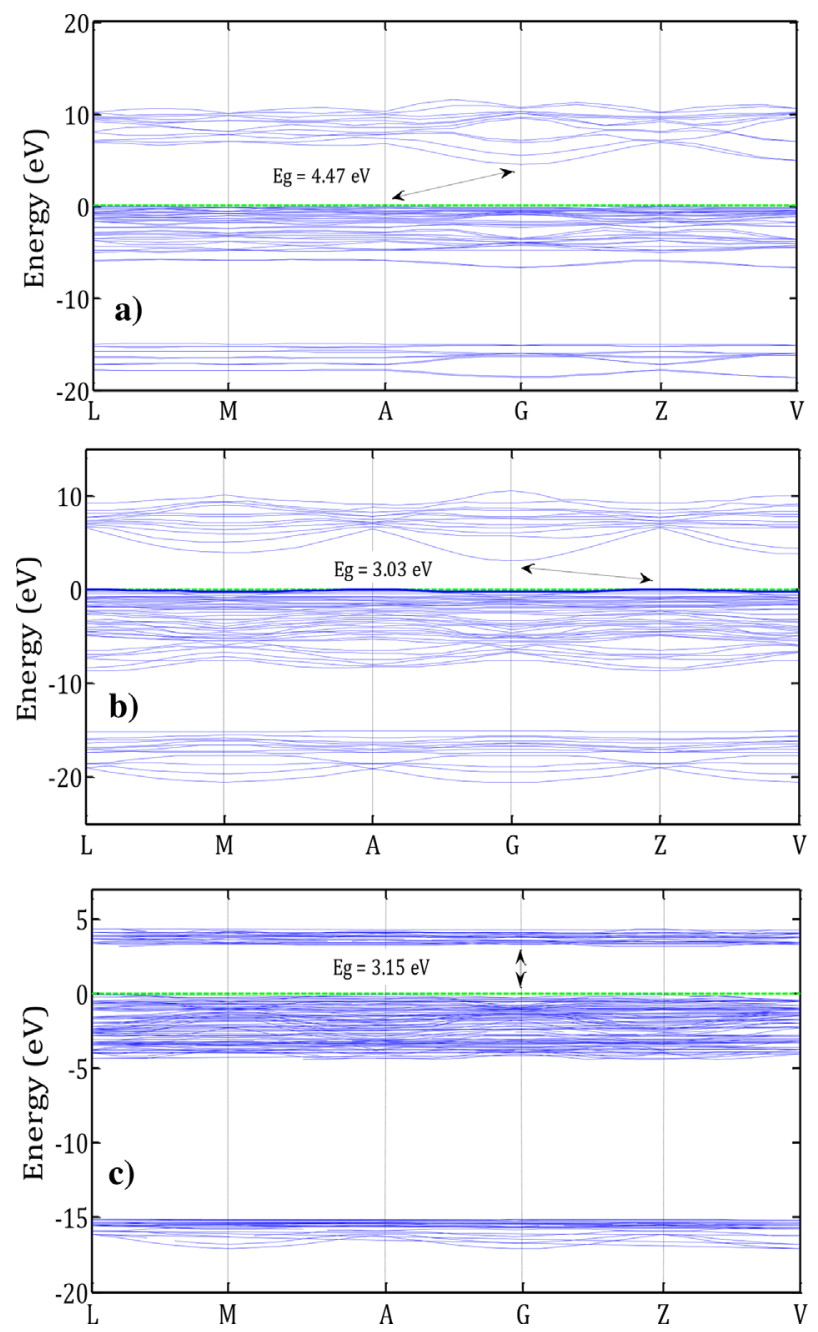

Figure 3. Band structures of (a) $\mathrm{Li}_{2} \mathrm{SnO}_{3}$, (b) $\mathrm{Li}_{2} \mathrm{Sn}_{6} \mathrm{O}_{13}$, and (c) $\mathrm{Li}_{2} \mathrm{Ti}_{6} \mathrm{O}_{13}$ calculated using the GGA + RPBE exchange-correlation functional. 
to the $\Gamma$-point at the conduction band minimum, resulting in $E_{\mathrm{g}}=3.0 \mathrm{eV}$.

On the basis of the computed energy gap, the $\mathrm{Li}_{2} \mathrm{Sn}_{6} \mathrm{O}_{13}$ compound emerges as a semiconducting material, but the calculated band structure displays an indirect gap from the Zpoint at the valence band maximum to the $\Gamma$-point at the conduction band minimum. Analogously, $\mathrm{Li}_{2} \mathrm{Ti}_{6} \mathrm{O}_{13}$ has also a semiconducting character with a direct gap from the Z-point at the valence band maximum to the conduction band minimum. The obtained Eg of the predicted compound $\mathrm{Li}_{2} \mathrm{Sn}_{6} \mathrm{O}_{13}$ is close to the experimental value for the $\mathrm{Li}_{2} \mathrm{Ti}_{6} \mathrm{O}_{13}$ and $\mathrm{Na}_{2} \mathrm{Ti}_{6} \mathrm{O}_{13}$ structures, $3.5 \mathrm{eV}$, while $\mathrm{K}_{2} \mathrm{Ti}_{6} \mathrm{O}_{13}$ has $E_{\mathrm{g}}=3.3 \mathrm{eV} .^{[9,38,41]}$

To further understand the electronic nature of these compounds, Table 6 displays the calculated $E_{\mathrm{g}}$ of each compound with respect to the exchange-correlation functionals employed. The errors of the mean value of $\mathrm{Eg}$ with respect to the experimental data ${ }^{[38,41]}$ are $\approx 16,11$, and $13 \%$ for $\mathrm{Li}_{2} \mathrm{Sn}_{6} \mathrm{O}_{13}$, $\mathrm{Li}_{2} \mathrm{Ti}_{6} \mathrm{O}_{13}$, and $\mathrm{Li}_{2} \mathrm{SnO}_{3}$, respectively. In view of the usual underestimation of DFT calculations, the errors are less than $30 \%$, making these values acceptable as lower-bounds. ${ }^{[13]}$ The mean value of $\mathrm{Eg}$ for the new compound $\mathrm{Li}_{2} \mathrm{Sn}_{6} \mathrm{O}_{13}$ is reduced to $0.18 \mathrm{eV}$ compared to that of $\mathrm{Li}_{2} \mathrm{Ti}_{6} \mathrm{O}_{13}$, and this result also emphasizes the efficient use of $\mathrm{Li}_{2} \mathrm{Sn}_{6} \mathrm{O}_{13}$ as an electrode in $\mathrm{Li}^{+}$. ion batteries.

One of the key requirements for a material to be efficiently used as an anode in lithium-ion batteries is that the material must be a good electronic conductor (preferably a metal). ${ }^{[42]}$ $\mathrm{Li}_{2} \mathrm{Ti}_{6} \mathrm{O}_{13}$ has a dc conductivity of $\sigma_{\mathrm{dc}}(T)=5.6 \times 10^{-6} \mathrm{~S} \mathrm{~cm}^{-1}$ at room temperature. ${ }^{[9]} \mathrm{As}^{\mathrm{Li}_{2}} \mathrm{Ti}_{6} \mathrm{O}_{13}$ is the parent structure leading to formation of the $\mathrm{Li}_{2} \mathrm{Sn}_{6} \mathrm{O}_{13}$ and in considering the results of the band gap energy of both compound, we can estimate the $\sigma_{\mathrm{dc}}(T)$ of $\mathrm{Li}_{2} \mathrm{Sn}_{6} \mathrm{O}_{13}$.

As the $\sigma_{\mathrm{dc}}(T)$ follows an Arrhenius type dependence $\sigma_{\mathrm{dc}}(T) \sim \exp \left(-E_{\mathrm{g}} / 2 k_{\mathrm{B}} T\right),{ }^{[43]}$ the reduction of $0.18 \mathrm{eV}$ of the energy gap with respect to the $\mathrm{Sn}^{4+}$ ion exchange in $\mathrm{Li}_{2} \mathrm{Ti}_{6} \mathrm{O}_{13}$ leads to an increment of the dc conductivity of $2.05 \times$ $10^{-4} \mathrm{~S} \mathrm{~cm}^{-1}$ for the unknown hexastannate compound. The estimated electrical conductivity of the new $\mathrm{Li}_{2} \mathrm{Sn}_{6} \mathrm{O}_{13}$ compound at room temperature is about two orders of magnitude higher compared with its hexatitanate counterpart. This value should be considered with caution because in real samples, other effects will affect the transport properties. Impedance spectroscopy measurements can reveal the electrical conductivity of the new compound when the compound is

Table 6. Energy gap (in eV) obtained using different DFT exchangecorrelation functionals.

\begin{tabular}{lccc}
\hline Exchange functional & $\mathrm{Li}_{2} \mathrm{Sn}_{6} \mathrm{O}_{13}$ & $\mathrm{Li}_{2} \mathrm{Ti}_{6} \mathrm{O}_{13}$ & $\mathrm{Li}_{2} \mathrm{SnO}_{3}$ \\
\hline PBE & 2.93 & 3.12 & 4.37 \\
RPBE & 3.03 & 3.15 & 4.47 \\
PW91 & 2.99 & 3.15 & 4.43 \\
WC & 2.85 & 3.09 & 4.24 \\
Mean & 2.95 & 3.13 & 4.36 \\
std & 0.02 & 0.003 & 0.03 \\
Error & 0.01 & 0.002 & 0.02 \\
\hline
\end{tabular}

prepared. However, this value provides us with a comparison between both compounds.

Other properties, such as the concentration of charge carriers (electrons and holes), are also proportional to $\exp \left(-E_{\mathrm{g}} / 2 k_{\mathrm{B}} T\right)$. As we have the proportion between the energy gaps of both compounds, we can estimate the influence of this small reduction on these properties by using the same procedure as above.

In order to determine the diffusion barrier in $\mathrm{Li}_{2} \mathrm{Ti}_{6} \mathrm{O}_{13}$ and $\mathrm{Li}_{2} \mathrm{Sn}_{6} \mathrm{O}_{13}$, we now use the force field-based nudged elastic band method, ${ }^{[4-46]}$ as implemented in GULP. ${ }^{[45]}$ The calculated energy barriers amount to 0.52 and $0.47 \mathrm{eV}$ for the $\mathrm{Li}_{2} \mathrm{Sn}_{6} \mathrm{O}_{13}$ and $\mathrm{Li}_{2} \mathrm{Ti}_{6} \mathrm{O}_{13}$ structures, respectively. The diffusion barrier in both compound agrees with, is even lower than, the values reported for other $\mathrm{Li}^{+}$based compounds, such as $\mathrm{Li}_{2} \mathrm{Ti}_{3} \mathrm{O}_{7}$ (0.67$\left.0.74 \mathrm{eV}^{[47]}\right)$, and other $\mathrm{Na}^{+}$counterparts $\left(0.9 \mathrm{eV}^{[48]}\right)$.

The fact that the energy barrier is lower in $\mathrm{Li}_{2} \mathrm{Ti}_{6} \mathrm{O}_{13}$ structure can be ascribed to the lower $\mathrm{Li}^{+}$jump distance into the $\mathrm{LiO}_{4}$ channel compared with $\mathrm{Li}_{2} \mathrm{Sn}_{6} \mathrm{O}_{13} \cdot{ }^{[12]}$ The small difference in energy barrier $(0.05 \mathrm{eV})$ again emphasizes the great potential of $\mathrm{Li}_{2} \mathrm{Sn}_{6} \mathrm{O}_{13}$ to be used as an alternative compound for lithium-ion batteries.

Equation (11) describes the lithiation/delithiation processes that occur in the negative/positive electrode in lithium-ion batteries. The term $\mathrm{Li}_{3} \mathrm{M}_{12} \mathrm{O}_{26}\left(\mathrm{LiM}_{6} \mathrm{O}_{13}\right)$ corresponds to the delithiated phase of $\mathrm{Li}_{2} \mathrm{M}_{6} \mathrm{O}_{13}$ compounds. It is well known that the cell voltage is directly associated with the chemical potential of lithium in the positive electrode. By using DFT calculations, the discharge voltage can be determined through the total energies of the lithiated and delithiades phases of $\mathrm{Li}_{2} \mathrm{M}_{6} \mathrm{O}_{13}$ compounds. The discharge voltage is calculated as follows ${ }^{[49-52]}$ :

$$
\begin{aligned}
V & =-\frac{E\left(\mathrm{Li}_{2} \mathrm{M}_{6} \mathrm{O}_{13}\right)-\left[E(\mathrm{Li})+E\left(\mathrm{LiM}_{6} \mathrm{O}_{13}\right)\right]}{F} \\
& =\frac{1}{4} \frac{q_{e} \Delta E(\mathrm{Li}) N_{A}}{F}
\end{aligned}
$$

where $F=9.65 \times 10^{4} \mathrm{C} \mathrm{mol}^{-1}$ is the Faraday's constant, $q_{e}$ the electron charge, $N_{A}$ the Avogadro's number and $\Delta E(\mathrm{Li})$ the overcalculated reaction energy of Li listed in Table 5 (in eV atom $^{-1}$ ). The calculated voltage values of the $\mathrm{Li}$ insertion/ extraction process per $\mathrm{Li}^{+} / \mathrm{Li}$ are 1.6 and $1.72 \mathrm{~V}$ for $\mathrm{Li}_{2} \mathrm{Sn}_{6} \mathrm{O}_{13}$ and $\mathrm{Li}_{2} \mathrm{Ti}_{6} \mathrm{O}_{13}$, respectively. Both voltage values are close to those experimentally reported, ranging between 1.5 and $1.7 \mathrm{~V}$ for $\mathrm{Li}_{2} \mathrm{Ti}_{6} \mathrm{O}_{13}$ and $1.3 \mathrm{~V}$ for $\mathrm{Na}_{2} \mathrm{Ti}_{6} \mathrm{O}_{13}$ compounds. ${ }^{[9,11]}$ These values are also comparable to those determined for the various phases of $\mathrm{TiO}_{2}$, which are also investigated as anodes for $\mathrm{Li}^{+}$-ion batteries. $^{[53]}$

Figure 4 displays the projected (PDOS) and total (DOS) density of states of $\mathrm{Li}_{2} \mathrm{Sn}_{6} \mathrm{O}_{13}, \mathrm{Li}_{2} \mathrm{SnO}_{3}$, and $\mathrm{Li}_{2} \mathrm{Ti}_{6} \mathrm{O}_{13}$. The DOS and PDOS plots of $\mathrm{Li}_{2} \mathrm{Ti}_{6} \mathrm{O}_{13}$ and $\mathrm{Li}_{2} \mathrm{Sn}_{6} \mathrm{O}_{13}$ structures, illustrated in Figure 4 a) and c), exhibit several similarities to those of $\mathrm{Li}_{2} \mathrm{SnO}_{3}$. The Li-s states contribution to the valence band is roughly similar, whereas that to the conduction band is quite accentuated. The Sn- $(s, p)$ states, combined with the O-p states, dominate the valence and conduction bands, revealing a $\mathrm{SnO}_{6}$ octahedral hybridization. On the other hand, the DOSs at both conduction and valence bands are much lower with respect to 

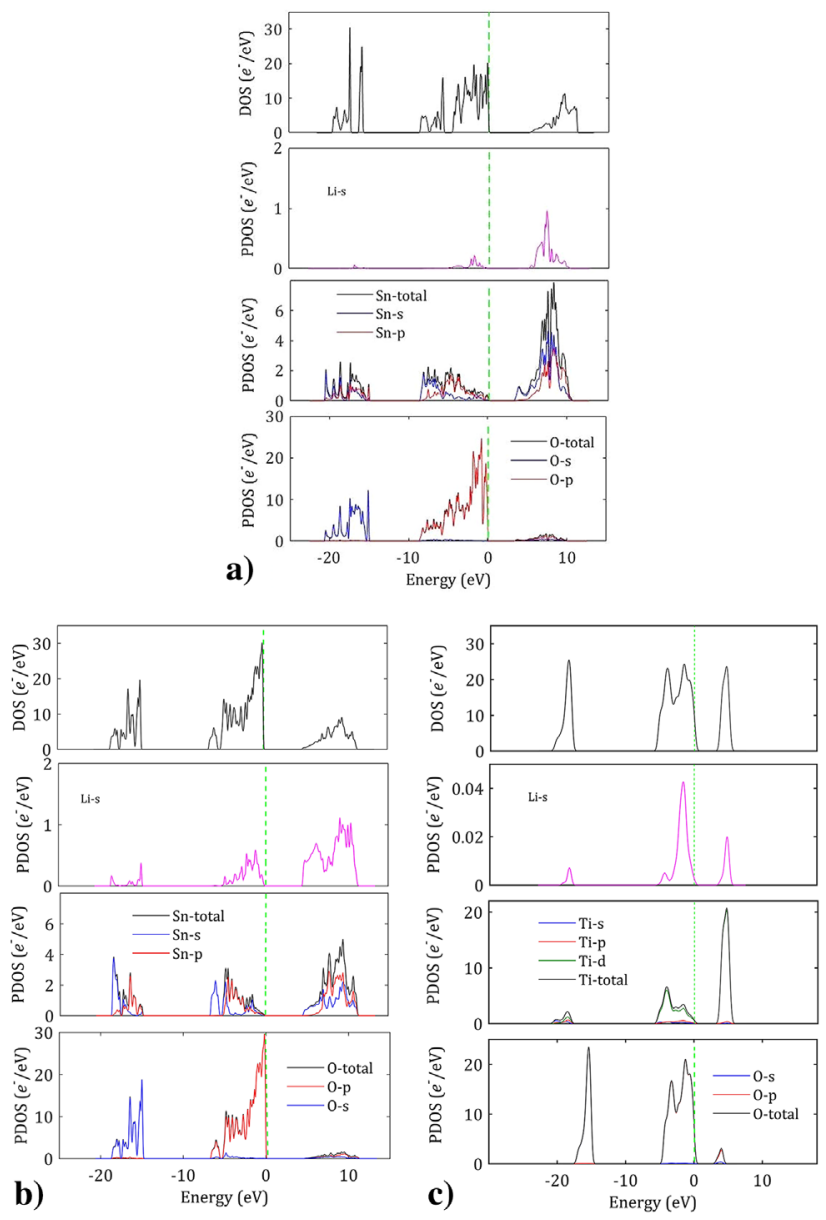

Figure 4. Total (DOS) and projected (PDOS) density of states of a) $\mathrm{Li}_{2} \mathrm{Sn}_{6} \mathrm{O}_{13}$, b) $\mathrm{Li}_{2} \mathrm{SnO}_{3}$, and c) $\mathrm{Li}_{2} \mathrm{Ti}_{6} \mathrm{O}_{13}$ in $\mathrm{C} 2 / m$ space group calculated using the GGA + RPBE functional.

those of $\mathrm{Li}_{2} \mathrm{SnO}_{3}$, in that the band gap energy has the lowest value. The characteristics of the DOS and PDOS of $\mathrm{Li}_{2} \mathrm{Ti}_{6} \mathrm{O}_{13}$ are quite comparable to those of $\mathrm{Li}_{2} \mathrm{Sn}_{6} \mathrm{O}_{13}$, confirming that they are partner structures (such as $\mathrm{Li}_{2} \mathrm{Ti}_{6} \mathrm{O}_{13}$ and $\mathrm{Na}_{2} \mathrm{Ti}_{6} \mathrm{O}_{13}$ ).

Bearing the different properties predicted for the new $\mathrm{Li}_{2} \mathrm{Sn}_{6} \mathrm{O}_{13}$ in mind, we can now propose that this compound features potential technological applications. In particular, it can be used as an alternative, or at least an auxiliary, material for energy storage. Its actual experimental synthesis and determination of its physicochemical properties are highly desirable. Compiling the abovementioned properties of $\mathrm{Li}_{2} \mathrm{Sn}_{6} \mathrm{O}_{13}$, it is highly required to complete the study of transport properties of this compound, specifically for $\mathrm{Li}^{+}$migration into its lattice structure. The aim of future work could involve theoretical predictions of $\mathrm{Li}^{+}$-migration by using classical simulations.

\section{Conclusions}

The structural, electronic and mechanical properties of $\mathrm{Li}_{2} \mathrm{SnO}_{3}$, $\mathrm{Li}_{2} \mathrm{Ti}_{6} \mathrm{O}_{13}$, and an unknown material $\mathrm{Li}_{2} \mathrm{Sn}_{6} \mathrm{O}_{13}$ were evaluated using classical simulations and DFT calculations. Mechanical properties were also determined by force-field methods and subsequently validated by DFT computations. After a full geometry optimization for each structure mentioned above, the elastic stiffness coefficients, bulk, shear and Young's moduli were calculated. To the best of our knowledge, the values for $\mathrm{Li}_{2} \mathrm{Ti}_{6} \mathrm{O}_{13}$ are reported for the first time in this work by using the force-field method. $\mathrm{Li}_{2} \mathrm{Sn}_{6} \mathrm{O}_{13}$ and $\mathrm{Li}_{2} \mathrm{Ti}_{6} \mathrm{O}_{13}$ are more elastically isotropic and more resistant with respect to volume change.

The lattice parameters obtained by DFT computations agree well with experiment, highlighting the values obtained via the use of GGA + RPBE functionals and the force field approach. This achievement provides us with a strong support for the capability of the force field to model this type of materials, it can be used for extensive search for new and interesting compounds.

The electronic band structure analysis points out the insulator character of $\mathrm{Li}_{2} \mathrm{SnO}_{3}$ with indirect band energy of $4.4 \mathrm{eV}$. In addition, both $\mathrm{Li}_{2} \mathrm{Ti}_{6} \mathrm{O}_{13}$ and $\mathrm{Li}_{2} \mathrm{Sn}_{6} \mathrm{O}_{13}$ appear to be semiconducting compounds with band gap energies of 3.1 and $3.0 \mathrm{eV}$, respectively. The thermodynamic stability of $\mathrm{Li}_{2} \mathrm{Ti}_{6} \mathrm{O}_{13}$ and $\mathrm{Li}_{2} \mathrm{Sn}_{6} \mathrm{O}_{13}$ are also reported. Both compounds are thermodynamically stable with a reaction energy for the lithiation of 6.4 and $6.9 \mathrm{eV}$ atom $^{-1}$, standard molar formation enthalpy of -5553 and $-6740 \mathrm{~kJ} \mathrm{~mol}^{-1}$ for $\mathrm{Li}_{2} \mathrm{Sn}_{6} \mathrm{O}_{13}$ and $\mathrm{Li}_{2} \mathrm{Ti}_{6} \mathrm{O}_{13}$, respectively. The predicted energy barriers for $\mathrm{Li}^{+}$migration amount to 0.52 and $0.47 \mathrm{eV}$ for $\mathrm{Li}_{2} \mathrm{Sn}_{6} \mathrm{O}_{13}$ and $\mathrm{Li}_{2} \mathrm{Ti}_{6} \mathrm{O}_{13}$, respectively. The calculated cell voltage values of $\mathrm{Li}$ insertion/extraction process per $\mathrm{Li}^{+} / \mathrm{Li}$ are $1.6 \mathrm{~V}$ for $\mathrm{Li}_{2} \mathrm{Sn}_{6} \mathrm{O}_{13}$. $\mathrm{Li}_{2} \mathrm{Sn}_{6} \mathrm{O}_{13}$ is characterized by mechanothermodynamic stability and electronic properties comparable to those of its partner structures $\left(\mathrm{Li}_{2} \mathrm{Ti}_{6} \mathrm{O}_{13}\right.$ and $\left.\mathrm{Na}_{2} \mathrm{Ti}_{6} \mathrm{O}_{13}\right)$.

In summary, the hexastannate compound, if it can be synthetized, is recommended as an alternative material for energy storage in $\mathrm{Li}^{+}$-batteries.

\section{Acknowledgements}

We are grateful to Professor J. D. Gale for allowing us to use the Gulp code. We also thank Ton Duc Thang University (Demasted), Vietnam, for support.

\section{Conflict of Interest}

The authors declare no conflict of interest.

\section{Keywords}

energy storage, Li migration barrier, lithium hexastannate, lithium hexatitanate, lithium stannate, standard formation enthalpy

Received: December 11, 2017 Revised: March 16, 2018 Published online:

[1] S. Chatterjee, K. Bhattacharyya, P. Ayyub, A. Tyagi, J. Phys. Chem. C 2010, 114, 9424.

[2] W. Zhou, H. Liu, R. I. Boughton, G. Du, J. Lin, J. Wang, D. Liu, J. Mater. Chem. 2010, 20, 5993. 
[3] K. Teshima, S. Lee, S. Murakoshi, S. Suzuki, K. Yubuta, T. Shishido, M. Endo, S. Oishi, Eur. J. Inorg. Chem. 2010, 2010, 2936.

[4] K. Teshima, K. Yubuta, T. Shimodaira, T. Suzuki, M. Endo, T. Shishido, S. Oishi, Cryst. Growth. Des. 2008, 8, 465.

[5] V. Štengl, S. Bakardjieva, J. Šubrt, E. Vecerníková, L. Szatmary, M. Klementová, V. Balek, Appl. Catal. B 2006, 63, 20.

[6] L. Zhen, C. Xu, W. Wang, C. Lao, Q. Kuang, Appl. Surf. Sci. 2009, 255, 4149.

[7] M. Vijayakumar, S. Kerisit, Z. Yang, G. L. Graff, J. Liu, J. A. Sears, S. D. Burton, K. M. Rosso, J. Hu, J. Phys. Chem. C 2009, 113, 20108.

[8] X. K. Zhang, J. J. Yuan, H. J. Yu, X. R. Zhu, Z. Yin, H. Shen, Y. M. Xie, J. Alloys Compd. 2015, 631, 171.

[9] K. Kataoka, J. Awaka, N. Kijima, H. Hayakawa, K. A. J. Ohshima, Chem. Mater. 2011, 23, 2344.

[10] J. C. Pérez-Flores, F. García-Alvarado, M. Hoelzel, I. Sobrados, J. Sanz, A. Kuhn, Dalton Trans. 2012, 41, 14633.

[11] J. C. Pérez-Flores, C. Baehtz, M. Hoelzel, A. Kuhna, F. GarcíaAlvarado, Phys. Chem. Chem. Phys. 2012, 14, 2892.

[12] Y. A. Zulueta, M. Froeyen, M. T. Nguyen, Comput. Mater. Sci. 2017, 136, 271.

[13] M. C. Payne, M. P. Teter, D. C. Allan, T. A. Arias, J. D. Joannopoulos, Rev. Mod. Phys. 1992, 64, 1045.

[14] J. P. Perdew, K. Burke, M. Ernzerhof, Phys. Rev. Lett. 1996, 77, 3865.

[15] B. Hammer, L. B. Hansen, J. K. Norskov, Phys. Rev. B 1999, 59, 7413.

[16] J. P. Perdew, J. A. Chevary, S. H. Vosko, K. A. Jackson, M. R. Pederson, D. J. Singh, C. Fiolhais, Phys. Rev. B 1992, 46, 6671.

[17] Z. Wu, R. E. Cohen, Phys. Rev. B 2006, 73, 235116.

[18] H. J. Monkhorst, J. D. Pack, Phys. Rev. B 1976, 13, 5188.

[19] D. W. Zhang, S. Q. Zhang, Y. Jin, T. H. Yi, S. Xie, C. H. Chen, J. Alloys Compd. 2006, 415, 229.

[20] N. V. Tarakina, T. A. Denisova, L. G. Maksimova, V. Baklanova, A. P. Tyutyunnik, I. F. Berger, V. G. Zubkov, G. Z. van Tendeloo, Kristallogr. Suppl. 2009, 30, 375

[21] J. C. Pérez-Flores, A. Kuhn, F. García-Alvarado, J. Power Sources 2011, 196, 1378.

[22] R. Shannon, Acta Crystallogr. A: Cryst. Phys. Diffr. Theor. Gen. Crystallogr. 1976, 32, 751.

[23] M. Born, J. Mayer, Z. Phys. 1932, 75, 1.

[24] M. Born, K. Huang, Dynamics Theory of Crystal Lattices, Oxford University Press, Oxford 1954.

[25] P. Canepa, K. Tan, Y. Du, H. Lu, Y. J. Chabal, T. Thonhauser, J. Mater. Chem. A 2015, 3, 986.
[26] J. F. Nye, Physical Properties of Crystals, Oxford University Press, New York 1957, pp. 140.

[27] F. Mouhat, F. X. Coudert, Phys Rev. B. 2014, 90, 224104.

[28] F. I. Fedorov, Theory of Elastic Waves in Crystals, Springer US, Springer Science + Business Media, New York 1968.

[29] A. R. Raffray, M. Akiba, V. Chuyanov, L. Giancarli, S. Malang, J. Nucl. Mater. 2002, 307-311 21.

[30] C. E. Johnson, J. Nucl. Mater. 1999, 270, 212.

[31] S. T. Murphy, P. Zeller, A. Chartier, L. Van Brutzel, J. Phys. Chem. C. 2011, 115, 21874

[32] S. F. Pugh, Philos. Mag. 1954, 45, 823.

[33] T. F. Yi, Y. Xie, Y. R. Zhu, R. S. Zhu, H. Shen, J. Power Sources 2013, 222, 448.

[34] M. Aydinol, A. Kohan, G. Ceder, Phys. Rev. B. 1997, 56, 1354.

[35] M. Holzinger, A. Benisek, W. Schnelle, E. Gmelin, J. Maier, W. Sitte, J. Chem. Thermodyn. 2003, 35, 1469.

[36] J. D. Cox, D. D. Wagman, V. A. Medvedev, CODATA Key Values for Thermodynamics, Hemisphere Publishing Corp, New York 1984.

[37] H. Gamsjäger, T. Gajda, J. Sangster, S. K. Saxena, W. Voigt, Chemical Thermodynamics of Tin, ISBN 978-92-64-99206-1, OECD, 2012.

[38] H. Manyu, L. Yimin, L. Chunguang, L. Xia, Physica B 2012, 407, 2811

[39] J. C. Pérez-Flores, C. Baehtz, M. Hoelzel, A. Kuhn, F. GarcíaAlvarado, RSC Adv. 2012, 2, 3530.

[40] A. Buljan, L. Padilla-Campos, Av. Cienc. Ing. 2010, 1, 37.

[41] J. A. Brant, D. M. Massi, N. A. W. Holzwarth, J. H. MacNeil, A. P. Douvalis, T. Bakas, S. W. Martin, M. D. Gross, J. A. Aitken, Chem. Mater. 2015, 27, 189.

[42] M. S. Whittingham, Chem. Rev. 2004, 104, 4271.

[43] C. Kittel, Introduction to Solid State Physics, Wiley, New York 1996

[44] G. Henkelman, H. Jónsson, J. Chem. Phys. 2000, 113, 9978.

[45] J. D. Gale, A. L. Rohl, Mol. Simul. 2003, 29, 291.

[46] N. Govind, M. Petersen, G. Fitzgerald, D. King-Smith, J. Andzelm, Comput. Mater. Sci. 2003, 28, 250.

[47] M. M. Islam, P. Heitjans, T. Bredow, J. Phys. Chem. C 2016, 120, 5

[48] A. L. Sauvet, S. Baliteau, C. Lopez, P. Fabry, J. Solid State Chem. 2004, $177,4508$.

[49] S. Islam, M. Craig, A. J. Fisher, Chem. Soc. Rev. 2014, 43, 185.

[50] M. Aydinol, A. Kohan, G. Ceder, J. Power Sources 1997, 68, 664.

[51] A. Samin, M. Kurth, L. Cao, AIP Adv. 2015, 5, 047110.

[52] J. A. Dawson, A. J. Naylor, C. Eames, M. Roberts, W. Zhang, H. J. Snaith, P. G. Bruce, M. S. Islam, ACS Energy Lett. 2017, 2, 1818.

[53] J. A. Dawson, J. Robertson, J. Phys. Chem. C 2016, 120, 22910. 